\title{
Towards a landscape ecosophy. Interpreting how the Villarrica- Pucón urban system inhabitants in the Araucanía region of Chile perceive and relate with the dynamics of Landscape
}

\author{
Rumo à uma paisagem ecosofia. Interpretando como os habitantes do sistema \\ urbano de Villarrica-Pucón, região Araucania do Chile, percebem e se \\ relacionam com a dinâmica da paisagem
}

Gonzalo Salazar ${ }^{[0]}$, Daniela Jalabert ${ }^{[b]}$

[a] Campus Villarrica \& Instituto de Estudios Urbanos y Territoriales, UC Centre of Local Development, Pontificia Universidad Católica de Chile, Villarrica, Chile

[b] UC Centre of Local Development, Pontificia Universidad Católica de Chile, Villarrica, Chile

\section{Abstract}

As a reaction to the complex global crisis, the notion of ecological urbanism has emerged in order to understand and attend the inaccuracy between the urban system and the environment of which it is a part. This article suggests that the form we perceive the city-nature relation deeply determines the praxis of urbanism arguing that the problem of ecological urbanism is essentially epistemological and ethical. Accordingly, the article introduces the concept of "landscape ecosophy" through which not only is possible to understand the indivisible connection of perception and socio-ecological practices, but also help us to reconnect the praxis of urbanism with a relational epistemology and landscape. The article empirically seeks to interpret how the Villarrica and Pucón urban system inhabitants in the Araucanía Region of Chile perceive and relate with the mountain and lacustrine landscapes in their daily practices of inhabitation. To achieve this, an ethnographic methodology is used. The discussion central line is represented by the question, 'So close, but so far?', as in spite of the fact that both cities are deeply connected to the landscape, their socio-cultural constructions are defined by the notions of disconnection and a lack of awareness. On the other hand, in a sort of circular causality, the article also identifies how certain urban initiatives may not only imply a reconnection between the urban system and the landscape of which it is a part, but also contribute to trigger the emergence of deeper landscape ecosophies.

Keywords: Ecological urbanism. Landscape. Ecosophy.

Resumo

Como forma de reação à complexa crise global, a noção de urbanismo ecológico surge com o propósito de compreender e responder à descalibragem entre o sistema urbano e o meio ambiente do qual este é parte. Ao argumentar que o problema do urbanismo ecológico é essencialmente epistemológico e ético, o presente

GS is doctor of Philosophy, University of Dundee, UK; Assistant Professor, Campus Villarrica \& Instituto de Estudios Urbanos y Territoriales, Pontificia Universidad Católica de Chile; Director of the UC Centre of Local Development, Pontificia Universidad Católica de Chile, e-mail: gonzalosalazar@uc.cl

DJ is researcher of the UC Centre of Local Development; Anthropologist, Universidad Austral de Chile; Master Asentamientos Humanos y Medio Ambiente, Pontificia Universidad Católica de Chile, e-mail: daniela.jalabert@hotmail.com 
artigo sugere que a maneira como percebemos a relação entre cidade e natureza determina profundamente a práxis do urbanismo. Neste sentido, o artigo introduz o conceito de "paisagem ecosofia", que permite tanto comprender a conexão indivisível entre prácticas de percepção e sócio-ecológicas, como também nos permite reconectar a práxis do urbanismo com uma epistemologia relacional e ética da paisagem. $O$ artigo procura interpretar empiricamente como os habitantes do sistema urbano de Villarrica e Pucón, cidades da Região Araucania do Chile, percebem e se relacionam com as montanhas e paisagens lacustres nas suas práticas diárias. Para tanto, é utilizada uma metodologia etnográfica. A linha central do debate é representada pela questão: "Tão perto, porém tão longe", pelo fato de que ambas as cidades, apesar de profundamente ligadas à paisagem, têm suas construções sócio culturais definidas por noções de desconexão e de falta de consciência. Por outro lado, numa espécie de causalidade, o artigo também identifica como certas iniciativas urbanas podem tanto implicar numa reconexão entre o sistema urbano e a paisagem do qual este é uma parte, como desencadear o surgimento de paisagens ecosofias mais profundas.

Palavras-chave: Urbanismo ecológico. Paisagem. Ecosofia.

\section{Introduction}

As neoliberal, socio-economic globalization has become an increasingly mass and universal phenomenon during recent decades; there is an emergent sensation and generalized certainty that global society, as defined by modern urban living, is triggering an unprecedented ecological crisis. In light of this, concepts such as ecological urbanism and design have emerged in response to this crisis, proposing changes on how the relationship between cities and the rest of the biosphere is understood and organized (Van der Ryn \& Cowan, 1996; Orr, 2002; Mostafavi, 2014). The conceptual and operative roots of this line of thinking can be found to a great measure in the emergence of a new scientific/philosophical paradigm which, focusing on the emerging global ecological crisis, proposes that the primary problem lays in the dominant modern dichotomies between reason-emotion, individual-environment, and city-nature. From mid-1950s, a new systemic or relational paradigm emerged through various disciplines and theories ranging from cybernetics, ecology, phenomenology, cognitive sciences, complexity mathematics, quantum physics, constructivism, and Gestalt psychology. This new paradigm left behind the mechanistic and reductionist visions of reality, leading to a new form of understanding the biosphere organization, and how humans inhabit it. Although the purpose of this article is not to explore the foundations of this new paradigm, especially as others such as Capra $(1996,2004)$ and Wilber $(2000 a, b)$ have already done so, it is necessary to emphasize that ecological urbanism must be understood within this framework. Thus, there are four fundamental and cross-cutting aspects to these emergent lines of thinking, which are important for ecological urbanism (Salazar \& Baxter 2015): 1) a criticism of the modern paradigm regarding its assumption of a transcendental reality that exists independently of human relations and experience; 2) that human perception is an embodied phenomenon, the knowledge point of departure and ways of inhabiting the world; 3 ) that the world where we live, or the phenomenological Being-in-the-World, is a dynamic relational process that is constantly changing, in which the being and the world are an inseparable phenomenon; and 4) that the wellbeing of humans and the rest of the biosphere are complementary (Primack et al., 2001).

In the field of urban planning and design, the visions of several authors have been central to providing a form for ecological urbanism along these lines: Patrick Geddes, at the end of the 19th century, called for a greater understanding of the interdependence between man and nature, cities development based on a holistic perspective, and to think globally and act locally regarding the environmental crisis facing the world (Geddes, 2010); Aldo Leopold, who using the concept of "land ethics", introduced the idea of the intrinsic value of other living beings and the rest of nature have, and the responsibility of humans to take care of the ecosystems that they inhabit (Leopold, 1990); Lewis Mumford, who as a critic of the early 20th century "mechanized" and "dehumanized" American 
urbanism, focused on generating an interdisciplinary vision that conceived of the city and regional development as the confluence of social, natural and technological elements in an integral and indivisible manner (Luccarelli, 1995; Wahl, 2006); Ian McHarg, who introduced the term ecological urban planning, which provides incentives for urban planners and designers to value and consider ecosystemic variables (McHarg, 1995; Wahl, 2006).

These precursory visions reflect certain central and apparently common elements regarding the theoretical discussion on a more ecological urbanism. Ultimately, these authors express that the actual problem of ecological urbanism is simultaneously 1) epistemological: this is to say, regarding how we understand the relationship between city and nature; and 2) ethical: i.e. regarding how we should relate to others, the rest of the biosphere, and future generations.

This epistemological and ethical foundation to urban ecology opens up a wide-ranging field of research aimed at understanding the relational dynamic between city and nature, in which the city is considered to be part of a larger ecosystem. However, this foundation is not always made very explicit, and is often ignored. In recent decades, research on cities has been dominated by a functionalist and productivist vision of economic, ecosystemic and cultural transformations. The perceptual dimension, on the other hand, through which we understand and value the relationship between cities and their surrounding environments, has been relegated to a secondary concern.

However, in order to take up and revalue the ecological urbanism research epistemological and ethical foundation, this article is based on the idea that the manner we perceive the relationship between the city and its natural ecosystem, informs and significantly determines the very praxis of urban-territorial planning. If in the context of an ecological paradigm, urbanism is understood as an experiential, cultural and territorially dependent phenomenon, it is important to adopt lines of research that consider this singularity. Such research must also reveal current perceptions and practices that serve as a basis for a more ecological and inclusive way of forming cities. Thus, among other challenges, it becomes necessary to interpret how the urban inhabitant understands and relates to the natural ecosystem encompassing he cityencompassing the city.

In order to approach such a research challenge, this article combines two ecological urbanism theoretical concepts, which have previously been vaguely related: landscape (understood as the eco-cultural hinterland of which an urban system is a part), and ecosophy (as a subjective orienting framework regarding the meaning and value that the urban inhabitant assigns to the landscape encompassing his or her city). The connection between these two concepts can be considered as "landscape ecosophy". Altogether, this term has two important implications to this research; the first is related to connecting the aspects of a relational (or socio-ecological) epistemology, which is implicit to the landscape concept, with the ethical aspects of the ecosophy that establishes how the individual (in this case the urban inhabitant) assigns meaning and value to the landscape encompassing the city. The second implication is related to scale. A "landscape ecosophy" implies the local scale revaluation, in favor of a more ecological urbanism in the globalized era. When localization becomes an inevitable phenomenon for the 21st century, in the context of global crises such as climate change and peak oil, it is necessary to imagine and value the importance of a smaller scale for organizing the dynamics of the city in a global era. This is about valuing and taking hold of the singularity of the place that we inhabit (Jackson, 1996; Barnhill, 1999; Goldstein, 1999), bioregionalizing the city (Aberley, 1999) and starting to position the city for higher organizational levels and productive self-reliance (Douthwaite, 1996; Shuman, 2000; Hopkins, 2008). A first step towards this achievement is understanding how the our contemporary cities inhabitants perceive and use their local landscapes, in order to begin to imagine the shift towards a more ecological urbanism.

First, the article generates a theoretical framework on landscape and ecosophy in order to construct the concept of landscape ecology. Based on this, a case study is presented. Here the paper seeks to interpret how the urban inhabitants of an urban-territorial system perceive and use the landscape encompassing their city. Finally, certain implications are discussed on the article central concept regarding the case study. 


\section{Landscape: a relational epistemology for ecological urbanism}

This research landscape concept value is marked mainly by the epistemological contribution that it provides on the person-environment and city-nature relationship. This concept has allowed researchers to move away from a static and predefined person and environment understanding (or city and nature) to a relational and indivisible one. For ecological urbanism, this is a fundamental clarification. The former view can be understood as epistemologically anti-ecological: the relationship between human and environment or city and nature is secondary, or even irrelevant, as each are defined a priori, before their interrelation (Ingold, 2000). Even more, the natural environment is conceived as a (Aristotelian) container in which the city and human-cultural actions are simply located. On the other hand, the concept of landscape is conceived as an ecological phenomenon per se: the landscape is a result of the relational dynamic of human habitation itself, in continuous interaction with social, cultural and environmental dynamics. Thus, the notion of landscape undoes the dichotomist assumptions regarding a "built" urban system and a "natural" system, in order to formulate one sole, interdependent system.

Soriano (2003, p. 29-30) builds upon this line of thinking by defining landscape as

[...] the result of the anthropic, physical and mental construction of every moment in history, which is determined and made possible by the natural environment, which in turn is constituted by abiotic and biotic factors.

Zuluaga's (2006) definition includes three dimensions, in which the first is objective (physical, geographical space) is subject to administration or government; the second is subjective (cultural) by which social groups attribute value to a portion of the geographic space; and the third is temporal (causal), as it is related to natural and human factors, and their respective interrelations. However, while these authors establish multidimensional patterns regarding the concept of landscape, they still divide landscape in different realms - i.e. in-out, mind-world, meaning-substance thereby neglecting or misunderstanding its relational essence. On the contrary, it is Ingold's (2000, p. 193) work that achieves a more integral definition: here
"[...] landscape is the world as it is known to those who dwell therein, who inhabit its places and journey along the paths connecting them". Landscape emerges as an inevitable, accumulative footprint; as a dynamics of human's embodied existence in continuous social and ecological interaction.

Landscape therefore is also a perceptual phenomenon. And as such, it cannot be dislodged from the influence of culture, as the latter is responsible for creating interpretations, archetypes and readings, depending on the existing social groups (Nogué, $1992,2008)$. Thus, the landscape is also, "a way of seeing" (Nogué \& de San Eugenio, 2011, p. 27). There is a certain rationality that is basically based on the way of being a part of a landscape. For this reason, "[...] the landscape valuation, although it seems to be sustained by certain instinctive aspects, is essentially cultural and learned [...]" (Alberto, 2009, p. 5). In other words, its perception is an experiential and relational phenomenon; it is an individual, physiological, and eco-cultural act.

\section{Towards a "landscape ecosophy"}

Landscape is a first step towards urbanism ecology. However, although the landscape notion is extraordinarily important in order to end the epistemological dichotomy between person and environment (or city and nature), it does not necessarily imply the emergence of more ecological behavior in urban-territorial planning and design (one that points, for example, to a better quality of life). Ecological urbanism that seeks out sustainability and quality of life also needs a guiding framework, mainly in the ethical-political dimension. An orienting framework for an ecological urbanism that seeks sustainability means, "[...] giving direction, guiding action, distinguishing between what is correct and incorrect, saying how one should act and live [...]" (Becker, 2012, p. 17). This is precisely what Arne Naess (1990) as well as Felix Guattari (2000) refer to with the term ecosophy.

For Naess (1990) the ecosophy is rational, personal philosophical system that leads one closer to deep ecology. Naess sought to transcend ecology as a science, centering on the study of the unity that emerges through interrelation, which is best approached by a combination between ecology and philosophy: eco-philosophy. It is through this platform that Naess 
introduces the term ecosophy, as a code of values and a way of seeing the personal world that guides one's decisions. Thus, he invites each individual to develop their own ecosophy, arguing that this is how more profound, ecologically social and institutionalized postures would emerge; i.e. through processes of unity within diversity. Thus, the personal rationality of the ecosophy is vital to be able to achieve processes of ecological urbanism. This occurs to the degree that the term ecosophy remains linked to the importance of the subject (subjectivity) in the processes of social and ecological transformation of those who utilize ecological urbanism. Along these lines, Guattari (2000) emphasizes that the current technocratic outlook - which Orr (2002) also explores through ecological design - is not really capable of dealing with the complexity of the prevailing crisis. Inversely, according to Guattari (2000, p. 27)

[...] only an ethic-political articulation - which I call ecosophy - between the three ecological registers (the environment, social relations, and human subjectivity) would be likely clarify [the issues of a planetary crisis].

It is in the combination of these three ecologies that the individual role - and especially the perception subjective dynamics that commands actions - becomes vital for ecological urbanism.

Ecological urbanism, to the degree that it enters into the practical and political arena in terms of how the city should be organized and planned to achieve a better quality of life, is not only inserted within the power dynamics itself. In addition, it also reveals a variety of visions, perspectives and practices regarding the city planning (or non-planning), and understanding it (or not) as part of a higher order landscape and biosphere.

The most complex issue here is related to the level of understanding on the ecological urbanism. Naess (1973) distinguished the difference between shallow ecology and deep ecology. While shallow ecology is focused on solving environmental problems through technological innovation and within an anthropocentric model, deep ecology is organized based on a foundational change, both epistemological and ethical, that recognizes and values the relational form of human beings as part of the biosphere network.

The combination of the term landscape and ecosophy, as it has been previously explained, leads to the emergence of what we refer to as a "landscape ecosophy". This is a personal system in which the relational epistemology of the landscape of which one is a part is combined with an orienting framework regarding how we should inhabit this landscape. A landscape ecosophy also demands "placing" or "localizing" ecological urbanism. This is to say, to plan and design the city and its relationship with a major landscape based on socio-cultural capacities, ecological limits and personal subjectivities of the various actors within the system. This is the landscape singularitywhich is revealed in all of its capacity and limits by a landscape ecosophy - in which ecological urbanism can really become developed in an appropriate manner, and thus deals with a global crisis.

Here, a significant empirical research dimension emerges: to examine the links between "the three ecologies" (Guattari, 2000) that actors in a certain urban system develop, specifically how they understand and relate inhabiting the urban system to the immediate and global landscape, encompassing the city.

\section{Case study and methodology}

With no doubt the urbanization processes - which in Chile reaches $86.6 \%$ (INE, 2002) - has generated significant ecological transformations on local scales, intertwined with a manner to understand the relationship between the city and its landscape. This situation is even more accentuated in the case of intermediate urban systems, due to their functional and cultural closeness with the surrounding hinterland.

Recently, the specialized literature has moved from the concept of "mid-size" cities to "intermediate" cities (Bellet \& Llop, 2004; Bolay \& Rabinovich, 2004) in order to reveal such cities importance on articulating different territorial and institutional scales-i.e. a unique role of intermediation between the urban and the rural, as well as the local and the global in economic, ecological and socio-cultural dimensions. In Latin America, intermediate urban systems tend to have a high level of connection with the local ecosystem where they are inserted, which implies a significant power of local ecological and cultural transformation, as well as a vital role for eco-cultural conservation and sustainable local and regional planning.

Regarding the empirical dimension, the current relationship between the Villarrica-Pucón urban 
system and its surrounding mountainous landscape (specifically the Villarrica National Park and the Villarrica Volcano) in the Araucanía Region of Chile has been used as a case study (Figure 1). Due to their "intermediation" role, Villarrica and Pucón socio-ecological and economic dynamics allow researchers to conceptualize and categorize them as an interdependent urban-territorial system. They not only have a strong relationship between themselves but also with the landscape they are within. That is, while it is not a conurbation, it would be inadequate to disassociate the two cities in this analysis as they share landscape, intercultural bouquet, and territorial and economic developmental aspects.

This urban system is part of the so-called Central Lacustrine Zone and the Glacial-Volcanic Plains (Gedda, 2010, p. 28). Within this system it is possible to discover lakes of glacial origin as tall as the Andes Mountain Range, a height level of endemic qualities pertaining to the Andean Temperate Forests and numerous volcanic centers (Gedda, 2010). This area makes up part of the Araucarias Biosphere Reserve, proclaimed by UNESCO (United Nations Educational, Scientific and Cultural Organization) in 1983 (RBARAUCARIAS, 2014). However, it is considered to be one of the most threatened areas of the country by

[...] urban expansion, the cutting and destruction of native forest habitat, grazing, forest fires and the introduction of invasive species as a result of human activity, and single-crop farming [...] (RBARAUCARIAS, 2014).

In addition, the area concentrates high indices of interculturalism, marked by the Mapuche culture

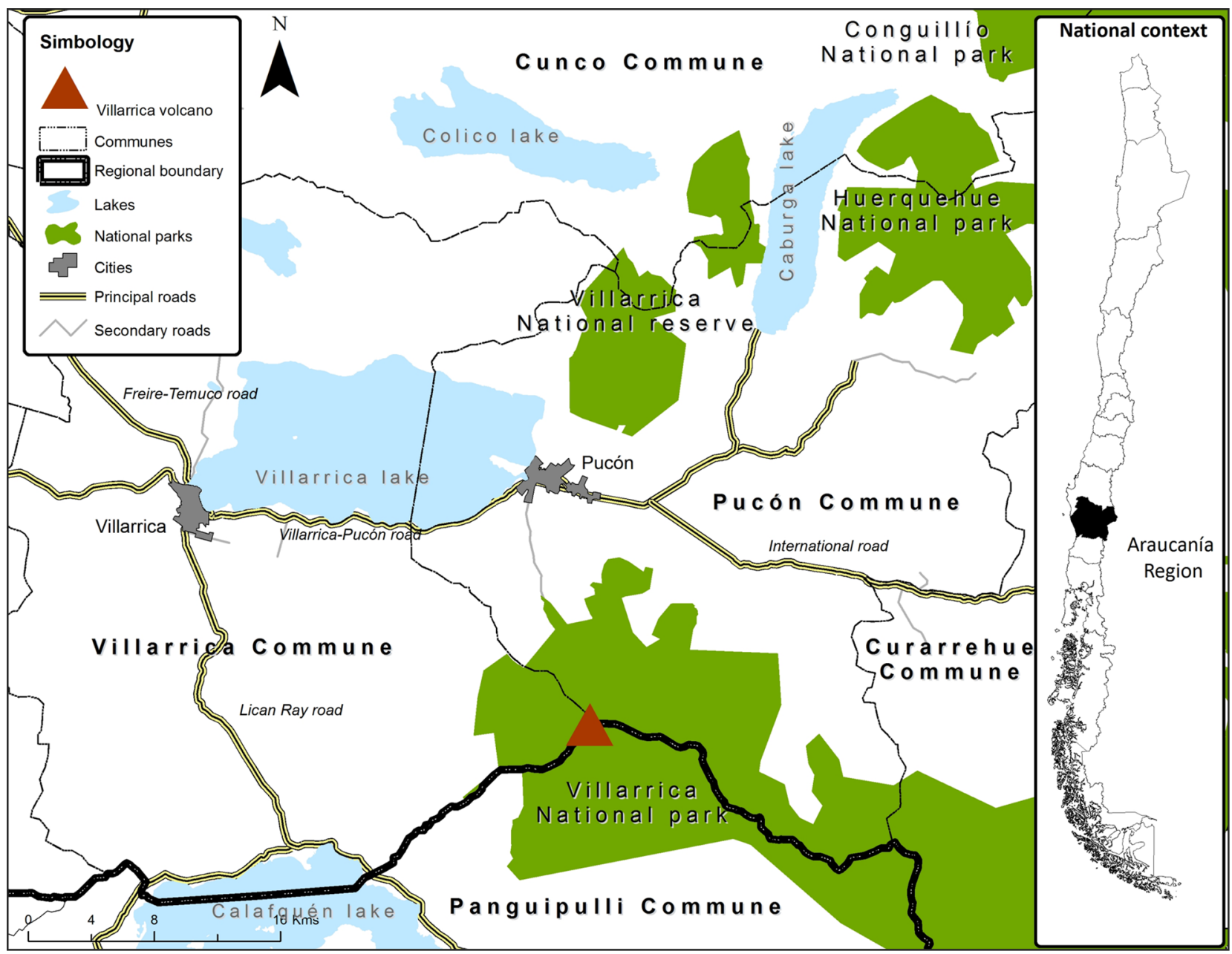

Figure 1 - Villarrica-Pucón urban system and its mountain-lacustrine ecosystem Source: Own Preparation with data from SIIT-BCN (Sistema Integrado de Información Territorial, Bibliotena del Congreso Nacional de Chile). 
(23.5\% of the indigenous population of Chile lives in this Region).

The Villarrica National Park is located in the Andean sector of the Araucanía Region, including the municipalities of Villarrica, Pucón and Curarrehue, as well as the Los Rios Region, including the municipality of Panguipulli. The Park includes an expanse of over 53,000 hectares (CONAF, 2014). Within the Park is the Villarrica Volcano, located southeast and northeast of the Villarrica and Calafquén Lakes, respectively. Its volcanic activity dates back to over 100,000 years, having experienced several eruptions during the 20th century $(1908,1948-49,1963-64,1971,1984$ and 2015).

This research methodological focus contributes to the discussion on the complexity between city and landscape from the perspective of several local actors who experience the place socio-ecological transformations where they live every day. Based on this methodological focus, work was done over a period of three years, using qualitative methods that emphasize an ethnographic approach. This ethnographic element of the research is intended to perceive

[...] the current realities, social entities and human perceptions, as they are and as they are present in themselves, without any intrusion or contamination from formal measures or preconceived problems [...] (Martínez, 2005, p. 2).

Empirical data was collected in two phases through semi-structured interviews with key informants. The first experience was developed over 9 months in 2013 , generating 20 semi-structured interviews with key local actors from the city of Villarrica (pertaining to the public, civil society and private sectors). The second data collection phase was between August and September of 2014, leading to the application of 30 semi-structured interviews with key informants from the public sector, as well as tourism operators of the mountainous areas. Local inhabitants were also interviewed. This second period included both the cities of Villarrica and Pucón (Table 1).

The formulation of the interview questionnaires focused on the following topics: (1) uses, practices and meanings attributed to the mountain and/or lacustrine landscape; (2) primary landmarks that occurred based on the Villarrica volcano and the Villarrica National park; and (3) processes and characteristics regarding urbanization and local sustainable development of the Villarrica - Pucón urban system. The informants were adults from 23 to 85 years of age; they were contacted personally by email and/or telephone, and each one agreed to the interview by reading and signing a letter of informed consent.

Table 1 - Sample description considered in semi-structured interviews

\begin{tabular}{|c|c|c|c|c|c|}
\hline \multirow{2}{*}{\multicolumn{2}{|c|}{ Sample description and numbers of interviewees }} & \multicolumn{2}{|c|}{ Villarrica-Pucón } & \multicolumn{2}{|c|}{ Temuco } \\
\hline & & \multirow{2}{*}{$\begin{array}{c}\text { Man } \\
14\end{array}$} & \multirow{2}{*}{$\begin{array}{c}\text { Woman } \\
2\end{array}$} & \multirow{2}{*}{$\begin{array}{c}\text { Man } \\
\end{array}$} & \multirow{2}{*}{$\begin{array}{c}\text { Woman } \\
-\end{array}$} \\
\hline Civil society (key speakers and common inhabitants) & $\begin{array}{l}\text { Man/woman who has been living in the area for more } \\
\text { than } 10 \text { years }\end{array}$ & & & & \\
\hline $\begin{array}{l}\text { Public sector (Municipal mayors; municipal public } \\
\text { workers) and university teachers }\end{array}$ & $\begin{array}{l}\text { Man/woman related to public decision making process } \\
\text { (in socio-cultural, ecological and economic sectors) in a } \\
\text { communal scale; and Man/woman related to academic } \\
\text { research (in cultural and planning studies) }\end{array}$ & 23 & 2 & - & - \\
\hline Technical officials from regional public offices & $\begin{array}{l}\text { Man/woman working on monitoring the volcano } \\
\text { Villarrica and Villarrica National Park }\end{array}$ & - & - & 2 & - \\
\hline Local tour operators & $\begin{array}{l}\text { Owners, guides or workers related to tourism companies } \\
\text { based in Villarrica and/or Pucón and that provide } \\
\text { services to Villarrica's Volcano and National Park }\end{array}$ & 6 & 1 & - & - \\
\hline
\end{tabular}

Source: Own preparation. 


\section{Ecosophies of urban inhabitation: observing the mountain landscape from afar}

From an ethic ${ }^{1}$ perspective, there is an initial tendency to consider that the Villarrica-Pucón urban system would have a direct relationship regarding experience and enjoyment of the Villarrica Volcano and National Park, as it is immersed in the mountainous landscape. However, based on the fieldwork, a recurring theme from the narratives of the interviewed subjects pointed to the very opposite. As this perception is quite internalized within the discourse of the majority of the interviewees, it is possible to determine the comprehension of the mountain landscape over the past 30 years as being subject to the following dichotomy: on the one hand, there is disconnection and lack of awareness; and on the other hand, an appropriation that translates territorially into identity and relevance for tourism.

Starting with the Villarrica Volcano, allusion is made to the fact that several decades ago, "[...] it was like a tradition to go to the volcano at least once in your life [or even] once a year" [...] $]^{2}$, or that, "[...] there were some families that walked, even from Pucón [...]"3, to the base of the volcano, leading to believe that the current disconnect has not always been the case among the urban population. However, as observed from the interviews made to actors pertaining to the civil society sector, at the same time, privatization and the charge of an entry fee have contributed to local residents refraining from making the trip.

Certain observations obtained from interviewees pertaining to the public, civil society and private sectors allow researchers to deduce that the socio-cultural mountain landscape construction is defined based on its distance from the resident population. Among the phrases that point this out are: "[...] people in other countries would be fascinated with our volcano, only half an hour from the city of Pucón; this is a privilege, people here have taken it for granted [...]"4; "[...] people always say that sometimes you don't even look at

\footnotetext{
${ }^{1}$ The point of view of someone who is not from the place in question.

${ }^{2}$ Interview with an inhabitant of Villarrica.

${ }^{3}$ Interview with an inhabitant of Pucón.

${ }^{4}$ Interview with an inhabitant of Pucón.
}

the volcano because you're so used to seeing it [...]"5; "[residents] like to look at the volcano from afar, but from close up I don't know too many people who say that they've actually been there [...]"6; "I think that half [of the population of Villarrica] have been to the volcano, but the rest just look from here [...]"7. Thus, the socio-ecological disconnection relationship with the volcano can be reduced to observing it from afar, rather than a feeling of really knowing it in the first person.

While it is certain that this disconnection is a constant within the narratives shared by the informants, it is worth noting that the notion of appropriation takes on a significant degree of strength within their imaginaries. This is because while there is no physical relationship, there is an important relationship on a subjective level. This generates a dichotomy in the socio-cultural definition of the landscape. On an emotional level, the disconnect completely disappears, as the 'looking from afar' is transformed into a looking that reveals the image of the volcano as an important iconic identify of the urban system. It comes to be conceived as a constituent element of the sense of belonging. This is because it is seen as the "flower vase of the city", the typical drawing made by school children, or the subject of conversation when one travels out of the city. Thus, the looking from afar does not prevent a certain feeling for the volcano, nor it is visually incorporated within daily life. This blooms into a series of meanings that represent the volcano in terms of "[...] inspiration [...]"; " [...] the beauty of nature in all its splendor [...]"; " [...] life, or that you see the earth represented there [...]"10.

The notion of appropriation, from the interviewees' perspective, is so relevant that it even leads to a metaphorical dispute between Villarrica and Pucón regarding to which city the volcano belongs. If the winner were to be judged by distance, Pucón would win as it is located at the volcano's base, and is the

\footnotetext{
${ }^{5}$ Interview with an official from the Emergency Office of the Municipality of Villarrica.

${ }^{6}$ Interview with an inhabitant of Villarrica.

${ }^{7}$ Interview with a tourism operator from Villarrica.

${ }^{8}$ Interview with a tourism operator from Pucón.

${ }^{9}$ Interview with an official from the Tourism Office of the Municipality of Villarrica.

10 Interview with a tourism operator from Villarrica.
} 
"[...] city's backdrop [...]"11; but Villarrica also claims victory, boasting that "[...] something that they don't have is the view, and that's why I think that in Villarrica this lakefront development emerged, with all of these buildings that look out on the volcano and the lake"12. Basically, the city structure and the possibility of seeing the volcano every day have an imperceptible influence on the process of appropriation, although in the same way the coming and going between the two cities facilitates the process by which the inhabitants unconsciously incorporate the mountain landscape as a defining element of their sense of belonging.

What happens when the radius is widened to include the Villarrica National Park? Even though its 53,000 hectares of abundant forest and vegetation surround the volcano and imbue its base with a deep shade of green, when asked about its relevance the unanimous response is that there is little connection with the Park. Some observations taken from the narratives show that there is also a certain lack of awareness regarding the relationship with the Park. Some of these include: "[...] there are probably even people who don't even know that the Park exists [...]"13, "[...] when you get there [to the volcano] you find the CONAF center, and only then can you tell that it's a National Park [...]"14, "[...] the local people aren't used to using the Park or nature as a source of recreation or contemplation [...]"15, or if "[...] you ask a random homeowner or student out in the street [...] they'll probably tell you that they didn't even know there is a National Park 15 kilometers outside of town [...]"16.

In the case of the Villarrica National Park, the primacy of this lack of awareness is interrelated with a lack of appropriation. On one hand, those who know the Park or who have heard of it, recommend it as a place to go, and thus incorporate it as part of the city's identity, though without changing the generalized lack of awareness. On the other hand, appropriation is institutionalized through the concept of State Protected

\footnotetext{
11 Interview with an official of the Municipality of Pucón.

12 Interview with an ex-official from the Emergency Office of the Municipality of Villarrica.

13 Interview with a tourism operator from Villarrica.

14 Interview with an official from the Tourism Office of the Municipality of Pucón.

15 Interview with an academic from the PUC Villarrica campus.

16 Interview with an official of the Municipality of Pucón.
}

Natural Areas (ASPE, for its Spanish acronym), or Biosphere Reserves. However, in practice this is an appropriation that is stronger on paper, and through the work of a particular group of experts, while still being very far from assimilated within the imaginary and socio-ecological relationships within the local community. There is a general observation that when

[...] you talk to the majority of people that live here in Villarrica or around here, it's not really a big deal for them, because they don't have a clear vision of what the Park means as a nature reserve, as protecting nature for future generations. They don't see it like that, so it's not important for them [...]. ${ }^{17}$

\section{Landscape instrumentalization of: Mountain tourism as an environmental economic project}

As manifested in some interviews and observed directly by the authors in the ethnographic process, when one walks down the streets of Villarrica and Pucón, in some ways the "looking from afar", which implies the lack of feeling and knowing the landscape in first person, comes into tension with the incorporation of an additional dichotomy regarding the relationship between the city and the mountain landscape. The names of businesses, flyers, arts and crafts fairs, tourism agencies and concession stands display a functional reality very connected to a major landscape. This also implies that a significant portion of the population does include such notions in their work, profession or projects.

According to Lowenhaupt (2008, p. 197), “[...] social and natural landscapes are made and remade in relationship with several environmental projects[...]", as "[...] each environmental project drives us to a transformed social and natural world through the way in which it combines significant ideas, policies and environmental practices". That is how the city's functionality ends up instrumentalizing the landscape. This is to say, it imbues the landscape with a use in order to achieve a certain purpose: a project for a city sustained on tourism, in which local, regional and national actors turn the landscape into "[...] a strategic instrument for defining both interventions and concrete actions in space [...]" (Zuluaga, 2006, p. 79).

17 Interview with a university professor from Villarrica. 
During the past 30 years, based on the information obtained in the interview by different local actors, it is possible to suggest that the mountain landscape instrumentalization takes on a socio-economic aspect that operates primarily within two areas:

First as a tourist commerce of the volcano and the Villarrica National Park. Starting at early 1980s, trips up to the volcanic crater, volcanic caves, canyoning, photography tours, ski trips and trekking became popular, together with new forms of cultural tourism such as indigenous and/or Mapuche tourism in the areas surrounding the Park. In the same way, large companies became incorporated into this new market, having been awarded public bids to build infrastructure, provide services, and maintain the National Park.

The second operational area is related to how the actions aimed at strengthening the tourism activity have a resulting influence on the ecological conservation and care for the landscape. Thus, mountain tourism becomes an environmental project that has sought professionalization in areas such as the generation of Tourism Quality Certifications and a National Registry of Tourism Service Providers provided by the National Tourism Service (SERNATUR). In addition, other actions such as the implementation of environmental municipal ordinances; the regulation of the number of people hiking the volcano ${ }^{18}$; the declaration of Areas of Interest for Tourism (ZOIT, for its Spanish acronym), among others, have also emerged. The branding of tourism experiences associated with concepts such as "ecotourism", "sustainable tourism", or experiences with "pristine nature" has also become common in recent years. Several local actors, including CONAF personnel, point to the fact that the establishment of tourism as the primary economic activity in the area, unlike the extractive forestry industry that had operated for several decades prior, has had favorable consequences for biological conservation and a cultural revaluation of the importance of such ecosystems for quality of life.

Both of these areas of operation - tourism development and the valuation of ecological conservation/care for the landscape - would seem to be functionally intertwined. Ultimately, understanding of the need to conserve and take care of the landscape through a more ecologically "innocuous" tourism seems to be

\footnotetext{
$\overline{18}$ Agencies can take a maximum of 24 people up at a time, and there must be one guide and one assistant for every 6 people.
}

not far from an economically based vision. This is to say, a vision focused on the use that the landscape can deliver for economic development of the urban system, and not primarily focused on the conservation of the mountain landscape as a value in and of itself.

\section{The Villarrica Lakefront: towards a landscape ecosophy based on urban habitation?}

From the point of view of urban development, the tourism boom has triggered significant spatial transformations, most of all regarding processes of urbanization, urban expansion, the development of commercial infrastructure, and real estate speculation. In the context of a heavily neoliberal planning system with an unregulated land market, this process would seem to be triggering a significant process of spatial segregation (see Zunino \& Hidalgo 2010; Hidalgo \& Zunino 2011). In the absence of strategic planning, the development of commerce and accommodation for tourists, real estate development of summer homes, and the prevalence of public services in areas of high tourism interest, have not only had negative socio-spatial consequences within the city. In addition, and as it was exposed by several actors for different sectors, there have also been negative consequences regarding the relationship between the local inhabitant and his or her natural surrounding landscape. Visiting the National Park and climbing up to the volcano become, or feel like, activities for a certain kind of visitor. At the same time, accessing the natural areas is no longer as easy as it once was, due to the processes of privatization and territorial atomization. The places with a better view, better connectivity, more scenic beauty, are no longer as open as they once were in past decades. This contributes to the fact that, in practice, the local inhabitant of the city is increasingly less physically connected to the landscape.

However, new urban projects seem to be effective on such unregulated urban-territorial planning. In particular, the new Villarrica Lakefront is a prime example. This place has been recurrently used by the interviewees in order to exemplify and embody the issues related to more inclusive urbanism, as well as to reflect on the influence that having such an urban space can have on the valuation, identity, recreation and even appreciation of the landscape.

The original project, developed by the Ministry of Public Works, involved the construction of an urban 
highway that would have ended up dislocating the city from its waterfront with the Villarrica Lake. Due to multiple factors this project triggered a social movement, which managed to detain the original project, install a basic level of public participation, and influence the design of a new project. In contrast, the new lakefront - inaugurated in December 2009 generated and articulated a pedestrian zone (which includes recreational, commercial and conservation areas and a new 400 meter long artificial beach - the latter inaugurated in December 2014) with a bikeway, a vehicular street and parking areas (Figure 2). The significant factor here however is related to the positive effects that this new space has generated for the inhabitants of Villarrica.

First, the fact that the public was able to organize and redesign a project so that it was more aligned with local requirements not only shows the importance of public participation in local urbanism but it also points to the value within the perceptual frameworks and local knowledge base regarding a more appropriate social and ecological design for the project.

Secondly, the Lakefront has emerged as a true platform for socio-ecological experiences, with significant implications for the relationship between the city and the rest of the landscape:

The lakefront became a central point for city life in Villarrica. To a significant degree. If it's a nice day, everybody goes there, to walk, to jog, to play. There was nowhere like that before. [...] the fact that there were no spaces before for people to

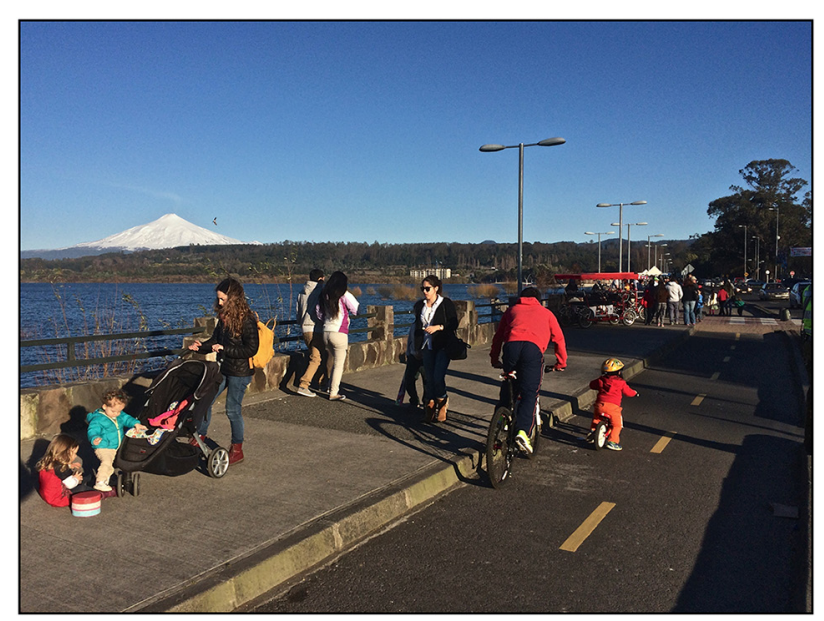

Figure 2 - The new Villarrica Lakefront Source: Picture taken by the authors, 2015. go, fomented the low levels of connection among the population [...]. [Nowadays], everybody recognizes that [the Lakefront has] changed the face of Villarrica, bringing it closer to the lake $[\ldots] .{ }^{19}$

This space is important to the city, bringing it closer to the lake and thus forming a closer identity to the rest of the landscape. This perception is triggered by the Lakefront use: a place for meeting fellow city dwellers, for experiencing the lake and the volcano that crowns the living landscape. It is in the resourcefulness of the urban space use that the basis is set for the emergence of a deeper ecosophy within the local actor:

When someone comes from out of town and values this, it starts to produce a change in you... everybody that comes says, "wow what a beautiful lakefront, it's like a different city". So then the [local] people start to think that yes, it does seem to be a good thing... certain spaces that they build, that encourage changes in attitudes, or certain things that can be strengthened that before hadn't been developed [...]. ${ }^{20}$

In the Lakefront case as a new urban space, what happened was an opening of the city to its surrounding landscape. It is a door, a threshold of daily use that invites the local inhabitant to look with new eyes upon the major landscape encompassing the city. To swim more in the lake, to observe in more detail the volcano together with others, and to feel that these elements of the ecosystem are also part of the urban routine, and thereby of their landscape ecosophy.

\section{Final considerations}

This work has been proposed as a contribution to the socio-cultural construction of the surrounding landscape compared to the urban habitat. The use of multiple perspectives (both perceptual and regarding habitus) by various urban actors allows us to observe that effectively the intermediate urban system and its surrounding landscape are related in a complex manner, to the point that neither one can really define

\footnotetext{
19 Interview with a university professor from Villarrica.

20 Interview with a President of a Municipal Union of an Urban Neighborhood Association.
} 
itself without the other. On one hand, this relationship leads us to understand the importance of studying local systems based on their particularities, and the perspectives of such constituent actors of a unique and continuously changing landscape. On the other hand, this relationship also suggests a high degree of complexity regarding the construction of landscape, in which projects perceptions, uses, meanings and a variety, that are even at times contradictory, are all interconnected. The recognition of these perceptions singularity and the multiplicity and landscape uses make up a significant portion of the ecology of urbanism.

The landscape relational construction emphasizes the need to transcend Cartesian visions that divide the city (as a cultural entity) from the environment (as a natural entity). However, despite the fact that this is increasingly evident in academia, it is not necessarily true in the ways of inhabiting the city itself. In practice, this case study speaks of an urban inhabitant that recognizes having a high level of disconnect with the surrounding landscape, which represents a dichotomy concerning several different aspects. The disconnection and instrumentalization of the surrounding landscape has strongly minimized the emergence of deeper ecosophies among the urban dweller. As such, the possibility of an ecological urbanism is also jeopardized. As a phenomenon that seem to be extended to many intermediate cities in Chile (and probably in the Latin American region) it is important that ecological urbanism takes on the challenge of generating a more deep-seated "ecological literacy" (Orr, 1992) within the urban inhabitant. This can be achieved by putting emphasis on facilitating an experiential closeness with the surrounding landscape. Such literacy is not only vital for the emergence of a more profound personal ecosophy. In addition - as has been observed in this research - it is vital for the contribution that it can have to providing ecological urbanism with value-based, emotional and cognitive bases that are more appropriate to particular places.

The case of the Villarrica Lakefront reinforces this point. As a variety of local actors are increasingly allowed to intervene in the opportunities for urban planning and design, there is a higher level of valuation not only of the project itself, but also of the activities that can take place in the new urban spaces that are developed. Thus, it would seem that ecological urbanism emerges not only from these perspectives, but in a sort of causal circularity, can also be a trigger and facilitator of epistemological and ethical frameworks that seek to install a more profound landscape ecosophy.

\section{Acknowledgements}

We thank the three anonymous reviewers for their constructive comments. This research was supported by the CONICYT Research Project Fondecyt Iniciación $\mathrm{N}^{\circ}$ 11130519, "Planificación y Desarrollo Urbano Local. Epistemologías de la Sustentabilidad en la Región de la Araucanía (Chile)"; by the Centro de Desarrollo Urbano Sustentable (CONICYT, FONDAP № 15110020, Chile); and by Interdisciplinary Centre for Intercultural and Indigenous Studies (CONICYT FONDAP № 15110006, Chile).

\section{References}

Aberley, D. (1999). Interpreting bio-regionalism: a story from many voices. In M. V. McGinnis (Ed.), Bioregionalism. New York: Routledge.

Alberto, J. (2009). Geografía y crecimiento urbano: paisajes y problemas ambientales. Geográfica Digital, 6(11), 1-13.

Barnhill, D. L. (1999). At home on the Earth: becoming native to our place: a multicultural anthology. Berkeley: University of California Press.

Becker, C. U. (2012). Sustainability ethics and sustainability research. Dordrecht: Springer.

Bellet, C., \& Llop, J. M. (2004). Miradas a otros espacios urbanos. Revista Electrónica de Geografía y Ciencias Sociales, 8(165).

Bolay, J., \& Rabinovich, A. (2004). Intermediate cities in Latin America risk and opportunities of coherent urban development. Cities, 21(5), 407-421. http://dx.doi. org/10.1016/j.cities.2004.07.007

Capra, F. (1996). The Web of life: a new synthesis of mind and matter. London: HarperCollins.

Capra, F. (2004). The hidden connections: a science for sustainable living. Anchor Books.

Corporación Nacional Forestal - CONAF. (2014). Parque Nacional Villarrica. Santiago. Retrieved in 26 June 2014, from http://www.conaf.cl/parques/parque-nacional-villarrica/ 
Douthwaite, R. J. (1996). Short circuit: strengthening local economies for security in an unstable world. Dublin: Lilliput Press.

Gedda, M. (2010). Patrimonio de La Araucanía: Chile. Manual de interpretación y puesta en valor. Villarrica: Ediciones Sede Regional Villarrica Pontificia Universidad Católica de Chile.

Geddes, P. (2010). Cities in evolution: an introduction to the town planning movement and to the study of civics. Charleston: BiblioBazaar.

Goldstein, B. E. (1999). Combining science and placebased knowledge: pragmatic and visionary approaches to bioregional understanding. In M. V. McGinnis (Ed.), Bioregionalism. New York: Routledge.

Guattari, F. (2000). The three ecologies. London: The Athlone Press.

Hidalgo, R., \& Zunino, H. (2011). Negocios inmobiliarios en centros turísticos de montaña y nuevos modos de vida. El papel de los migrantes de amenidad existenciales en la Comuna de Pucón - Chile. Estudios y Perspectivas en Turismo, 20(2), 307-326.

Hopkins, R. (2008). The transition handbook: from oil dependency to local resilience. Totnes: Green Books.

Ingold, T. (2000). The perception of the environment: essays on livelihood, dwelling and skill. London: Routledge.

Instituto Nacional de Estadistica - INE. (2002). Censo 2002: síntesis de resultados. Santiago de Chile. Retrieved in 26 June 2014, from http://www.ine.cl/cd2002/sintesiscensal.pdf

Jackson, W. (1996). Becoming native to this place. Washington: Counterpoint.

Leopold, A. (1990). A sand county almanac: with essays on conservation from round river. New York: Ballantine Books.

Lowenhaupt, A. (2008). La naturaleza en construcción. In L. Montenegro (Ed.), Cultura y naturaleza: aproximaciones a propósito del bicentenario de la independencia de Colombia (p. 196-224). Bogotá: Jardín Botánico de Bogotá José Celestino Mutis Centro de Investigación y Desarrollo Científico.

Luccarelli, M. (1995). Lewis Mumford and the ecological region: the politics of planning. New York: Guilford Press.

Martínez, M. (2005). El método etnográfico de investigación. Retrieved in 26 June 2014, from http://investigacionypostgrado. uneg.edu.ve/intranetcgip/documentos/225000/225000a rchivo00002.pdf
McHarg, I. L.(1995). Design with nature. St. Louis: Turtleback Books.

Mostafavi, M. (2014). ¿Por qué urbanismo ecológico? ¿Por qué ahora? (Urbanismo ecológico). Barcelona: Gustavo Gili.

Naess, A. (1973). The shallow and the deep, long-range ecology movement: a summary. Inquiry, 16(1), 95-100. http://dx.doi.org/10.1080/00201747308601682

Naess, A. (1990). Ecology, community, and lifestyle: outline of an ecosophy. (D. Rothenberg, trans.). Cambridge: Cambridge University Press.

Nogué, J., \& de San Eugenio, J. (2011). La dimensión comunicativa del paisaje. Una propuesta teórica y aplicada. Revista Geografía Norte Grande, 49(49), 25-49. http:// dx.doi.org/10.4067/S0718-34022011000200003

Nogué, J. (1992). Turismo, percepción del paisaje y planificación del territorio. Estudios Turísticos, 115, 45-54.

Nogué, J. (2008). Introducción: la valoración cultural del paisaje en la contemporaneidad. In J. Nogué (Ed.), El paisaje en la cultura contemporánea (p. 9-24). Madrid: Editorial Biblioteca Nueva.

Orr, D. W. (1992). Ecological literacy: education and the transition to a postmodern world. New York: SUNY Press.

Orr, D. W. (2002). The nature of design: ecology, culture, and human intention. New York: Oxford University Press.

Primack, R. B., Rozzi, R., Feinsinger, P., Dirzo, R., \& Massardo, F. (2001). Fundamentos de conservación biológica: perspectivas latinoamericanas. México: Fondo de Cultura Economica.

Reserva Biósfera Araucarias - RBARAUCARIAS. (2014). Antecedentes de la Reserva. Retrieved in 27 November 2014, from http://rbaraucarias.cl/rbaraucarias/

Salazar, G., \& Baxter, S. (2015). Towards an ecology of design praxis. The Design Journal, 18(3), 421-438. http:// dx.doi.org/10.1080/14606925.2015.1059608

Shuman, M. (2000). Going local: creating self-reliant communities in a global age. New York: Routledge.

Soriano, M. (2003). ¿Cómo se construye el paisaje? In En Organismo Autónomo de Parques Nacionales (Ed.), La humanización de las altas cumbres de la Garona y las Nogueras (4.500 a.C.-1955 d.C.). Parte 3 Naturaleza y Parques Nacionales: Serie histórica (p. 21-41). Principado de Asturias: Editorial Red de Parques Nacionales. 
Van der Ryn, S., \& Cowan, S. (1996). Ecological design (1st ed.). Washington: Island Press.

Wahl, D. C. (2006). Design for human and planetary health: a holistic/integral approach to complexity and sustainability. Dundee: University of Dundee.

Wilber, K. (2000a). A brief history of everything. Boston: Shambhala.

Wilber, K. (2000b). Sex, ecology, spirituality: the spirit of evolution. Boston: Shambhala.
Zuluaga, P. (2006). Una Mirada al paisaje como recurso turístico. Revista Interamericana de Ambiente y Turismo, 2(2), 76-82.

Zunino, H., \& Hidalgo, R. (2010.) En busca de la utopía verde: migrantes de amenidad en la comuna de pucón, IX Región de la Araucanía, Chile. Revista Electrónica de Geografía y Ciencias Sociales, 14(331).

Received: June 18, 2015

Approved: Oct. 02, 2015 